\title{
Innovative Activity And Change Tendencies Of Some Of Polish Industry's Economic Indicators
}

Adam Mazurkiewicz, (E-mail:Adam.Mazurliewicz@itee.radom.pl), Institute for Terotechnology, Poland Jerzy Dobrodziej, Institute for Terotechnology, Poland

Rozalia Sitkowska, Institute for Terotechnology, Poland

\begin{abstract}
The article discusses innovation in Polish industry in light of OECD indicators and the authors' own study. The problem of innovation in Polish industry is presented from the point of view of the following topics: adjusting Polish industry's structures to the requirements of knowledge-based global industry; raising the efficiency of some industry sectors as a result of an improved transfer of innovative achievements, the concentration of capital available, especially that obtained from the EU Structural Funds and offset deal, on the investments conducive to the economy's growth by means of implementing innovative solutions.
\end{abstract}

The article presents the results of analyses of the economic indicators in some industry sectors in Poland based on innovative activity. In line with the Classification of Products by Activity in the European Union (CPA), the following sectors have been highlighted: the Sector of Consumer Goods Production, the Sector of Delivery Goods, the Sector of Investment Goods (the main vehicle of technological progress for Polish industry).

Based on the results of the analysis, change tendencies have been identified for economic indicators as enabled by innovative potential. Prognostic models for economic indicators have been proposed that help estimate the influence of innovative potential on the growth of Polish industry. An example has been presented for applying the prognostic model using an Artificial Intelligence Method.

\section{Introduction}<smiles>C1CC2CCCC(C1)C2</smiles>

$\mathrm{n}$ the world economy an evolution takes place that concerns the transformation of the economy based on work and capital into knowledge-based economy which is a substantial economic resource. The basis for the occurring changes is an assumption that the knowledge and skills are an economic category and the knowledge transformation, as well as the technology transfer take place through the use of market mechanisms. The evolution occurring in the global economy is a result of experiences of well developed countries, where the society's knowledge in the process of creating new technological solutions contributes to economic successes and the competitive position in the world market. The significant factor in the new knowledge based economy model is the innovativeness. Countries derive a lot of benefits from the high innovativeness. The innovativeness causes in particular: decisive improvement of the economy competitiveness, better quality of the offered products - usually most technologically advanced, upgrade of the social education - resulting among others in the unemployment decrease, and improvement of the environmental protection. The effective innovativeness improvement requires the following activities: concentration of means in the area of advanced technologies, adaptation of the education level to the high standard of the knowledge-based society, promotion of the innovation diffusion into economy and supporting the research and development sector. 
The great meaning of the innovativeness to the development of the modern economy was reflected in the priorities of the EU policy agreed at the Lisbon summit (2000). The result of the strategic development directions of the EU are the operational activities, in particular the Sixth Framework Programme of the European Community for Research and Technological Development 2002-2006 which has contributed to the creation of the European Research Area. In this programme the activities were undertaken that concern the basic areas of the innovative policy. The operational activities of the Sixth Framework Programme aim to create the European Search Area that is a vision of the European science in the perspective of the nearest 20 years.

Poland, similar as the European Union is the object of a growing competitiveness pressure, coming from the global world economy. In order to decrease the technological gap and the difference in the standard of living between Poland and the well developed countries as well as take the advantage of the chance resulting from the EU membership, Poland has to make an effort to develop a strong, stable and competitive economy. One of the strategies enabling reaching the world standards by the Polish economy is the consistent implementation of the innovative solutions into the economy.

\section{Innovativeness of the Polish economy in comparison with well developed countries}

The Polish economy has one of the lowest innovativeness indices in Europe. The truthfulness of the thesis is confirmed by the assessment carried out by OECD, in particular the value of the synthetic index of the development level of the knowledge-based economy (fig.1).

Fig. 1. The synthetic index of the development level of the knowledge-based economy in OECD countries

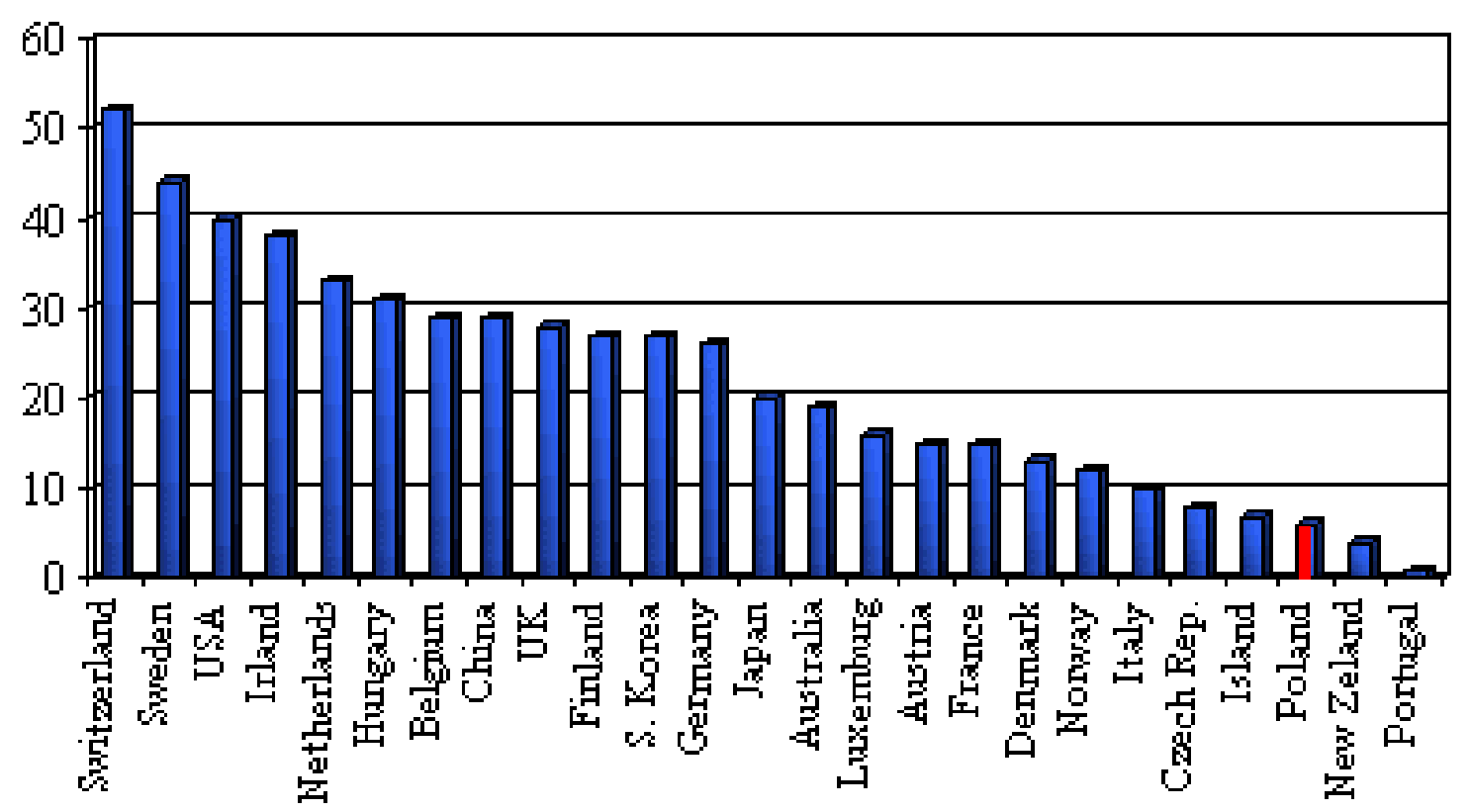

Source: Financial Times, 30.10.2001 for [1], [11].

Poland holds a significant potential of the scientific and research development that includes among others 375 higher schools, over 200 research development institutes and 80 institutions of the Polish Academy of Sciences (PAN), as well as many organisational structures supporting the innovativeness (IRC, TDAC, technological parks, etc.). In Poland the number of people with higher education has been rising permanently. The index of the students growth per 10 thousand of people rose in Poland in the 90s almost four times and is one of the highest indices 
among the European countries (1.8 in Greece, 1.7 in Portugal and 1.4 in Spain). The successes of institutions participating in the $5^{\text {th }}$ Framework Programme of the European Community for Research, Technological Development and Demonstration Activities (1998-2002) prove of the meaning of the Poland's scientific potential. Among the countries of the Central and Eastern Europe the Poland's participation in the $5^{\text {th }}$ Framework Programme was the most significant, both as regards the amount of submitted projects (855) and those ones accepted for realisation (167).

In the $6^{\text {th }}$ Framework Programme started in 2002 Poland is also very active (fig. 2) both in the proposed projects (9\%) and in those tentatively accepted for the realisation (4\%).

Fig. 2. Ranking of the EU countries and the associated Countries as regards to the EoI submitted and positively assessed in the $5^{\text {th }}$ Framework Programme

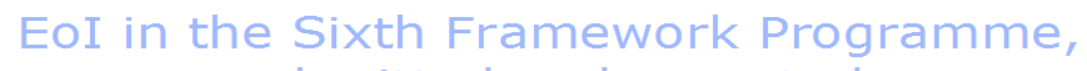
submitted and accepted

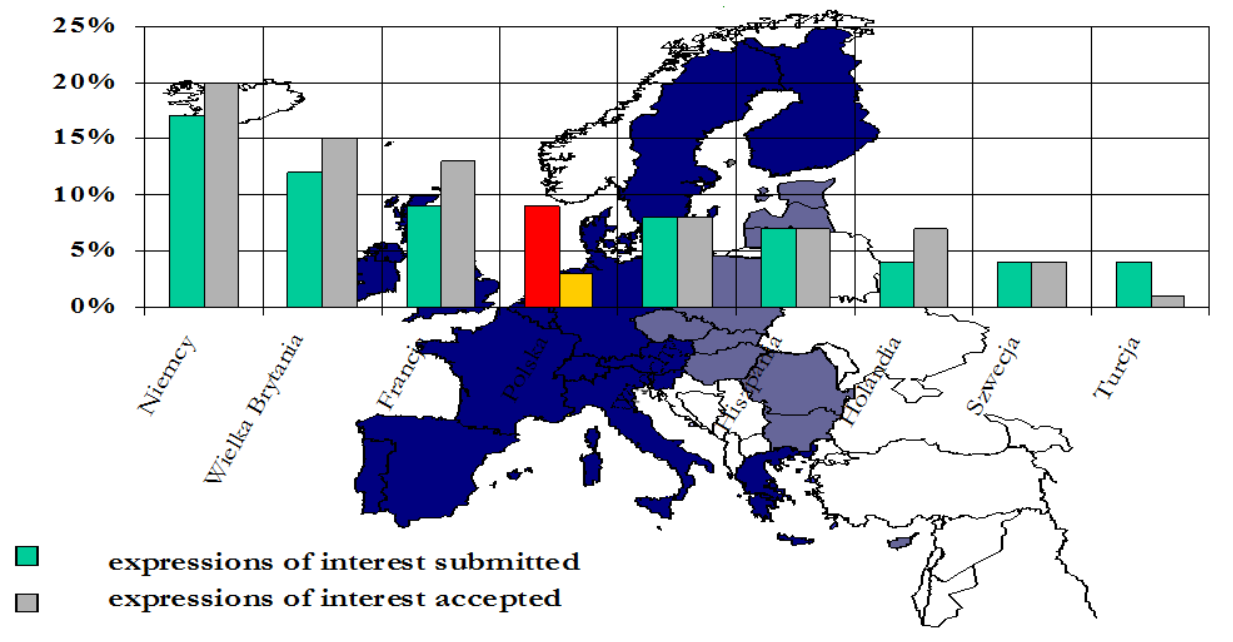

At the same time, within the framework of the so called targeted projects financed by the State, many innovative works are being realised (fig. 3). Those innovative works are orientated towards the application into the industry and the whole economy, although their number is falling alarmingly. The reason for such situation are the economy tendencies occurring in the last years (decline of the GDP - from $7 \%$ in 1995 to $1 \%$ in 2001).

The level of financing the scientific research in Poland GERD/GDP is relatively low and amounts to $0.65 \%$ in 2001, while on average in the OECD countries $-2.17 \%$, and in the UE - $1.81 \%$.

However, the total "investment in knowledge" ${ }^{1}$ was estimated in the OECD countries on $4.7 \%$, in the UE $3.6 \%$, and in the United States, Sweden and Finland from 5.2\% to 6.5\%. In Poland the spending on the R\&D activity, including the public and private expenditure on higher education, referring to the GDP in years 1995-2001 amounted to $1.92 \%$. The spending on the R\&D in Poland is similar to the spending of Greece, Republic of South Africa and Slovakia [4].

\footnotetext{
${ }^{1}$ In "The OECD Science, Technology and Industry Scoreboard 2001" it was assumed to count the following expenditure in the investment in knowledge: expenditure on the R\&D activity, public and private spending on higher education and spending on the investment in software [4].
} 
Fig. 3. The number of the targeted projects

Co- financed from the State budget in years 1992-2002.

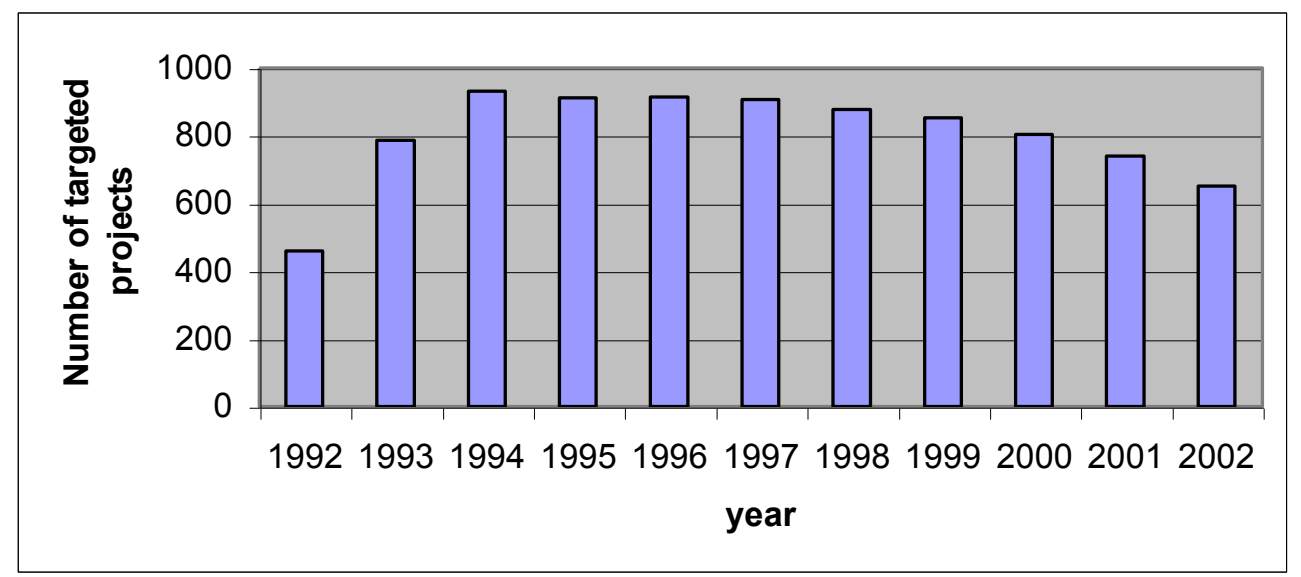

Source: Database on the targeted projects of the State Committee for Scientific Research $(K B N)$ - own research.

The innovative activity is characterised by a very low share of private funds allocated for the R\&D activities in the economy. In $200135.2 \%$ of the spending on science in Poland came from the non-budgetary means, while in the EU countries $65.4 \%$ and in the USA 72.4\%. However, the share of the financing from non-public resources is higher in Poland than, for instance in Portugal, Argentina and Mexico [9].

In Poland there is an insignificant share of the research programmes co-financed from the State budget, supporting the private institutions. At the same time the private foundations supporting the research activity in the USA and in Germany win about $80 \%$ of means from the State budget, and in Sweden about $60 \%$.

In the field of the entrepreneurship and innovativeness the foreign investments play a very important role. In spite of the tendency for increasing the investments in the sectors of high technology the structure and quality of foreign investments is still not satisfactory in comparison with Czech Republic or Hungary. It is estimated that the total value of direct foreign investments in Poland in 1995-2001 amounted to ca. 34 billion dollars and this gives Poland a lead in the region. However, there were insufficient means from the foreign investments located in the high technology sectors, such as: information science, nanotechnology or mechatronics, advanced services for business as well as biotechnology. In Poland the extension of the direct American investments is expected - their share increased from 3.5\% in 2000 to $10.3 \%$ in 2001 [8]. At present the value of American investments in Poland is greater than in Czech Republic, but decidedly smaller than in Hungary. An example of such investments can be the transmission of engines for the F-16 planes production technology to Communication Equipment Factory WSK Rzeszów, where at the same time one of many programmes being realised is a programme concerning the simulation of the processes of the sheet-metal elements forming. In this programme which is being implemented by the Institute for Terotechnology in Radom participate also the authors of this article.

\section{The innovative potential of selected sectors in the Polish industry}

The restructuring of the political system has significantly influenced the innovative potential in the Polish industry. The dynamics of the innovative expenditure in Poland in the period of restructuring the economy is showed in fig. 4. 
Fig. 4. The dynamics of the investment spending in the Polish economy in 1991-2002

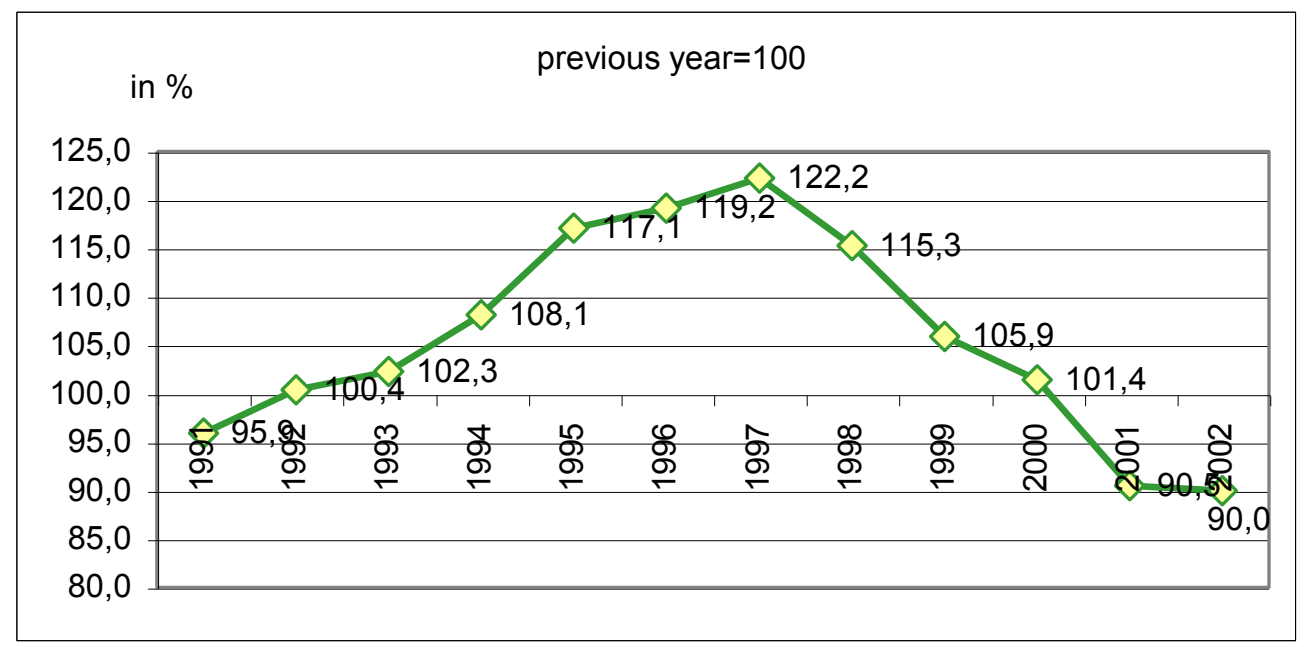

Source: [9].

The result of changes that had occurred after 1989 in the privatisation sector of the industry was a crucial phenomena which have influenced the innovative processes:

- closing down the production in many high-tech branches for the sake of the quality and price competitiveness on the European and world markets, e.g. closing-down the production of semiconducting elements, sub-assemblies and electronic devices,

- $\quad$ permanent decrease of the production and the employment in the high technology industry. The industrial plants of this kind were employing 257 thousand people in 1989, 169 thousand in 1995 and only 145 thousands in 2001.

- $\quad$ decrease of the number of people working in sectors connected with the R\&D of industrial plants (from 42 thousand of people in 1989 to 13.9 thousand in 2001).

At present there are several industrial groups in Poland creating different models of innovativeness. State enterprises, branches of the international concerns and small and medium-sized enterprises are either not interested in the investment in research or they do not have appropriate financial capabilities. The state enterprises contend with serious financial difficulties; branches of large western enterprises use predominantly laboratories located in their native countries and the SME's sector, for the reason of the economic weakness and the lack of capital, uses the high-tech innovative solutions in a limited scope. In the recent years there is a group being created which is constituted of larger State enterprises (employing ca. 500-600 employees) and possess the indispensable capital. Owners of those enterprises invest effectively in the technological development and in the innovative solutions implementation.

For the needs of the analysis of the innovative potential of the Polish industry the authors chose, in accordance with the European Activity Classification, the following sectors ${ }^{2}$ :

\footnotetext{
${ }^{2}$ This division was based on the Polish Activity Classification, valid from 2001 which is a modification of the European Activity Classification. Sector $\mathrm{K}$ includes the following production branches: manufacture of food products and beverages, manufacture of tobacco products, manufacture of textiles, manufacture of wearing apparel and furriery, processing of leather and manufacture of lather products, manufacture of furniture; manufacturing n. e. c. Sector P encompasses: manufacture of coke, refined petroleum products, manufacture of wood and wood, straw and wicker products, manufacture of pulp and paper, manufacture of other non-metallic mineral products, manufacture of basic metals, manufacture of metal products. Sector W encompasses: manufacture of chemicals and chemical products, manufacture of rubber and plastic products, manufacture of machinery and equipment n. e. c., manufacture of office machinery and computers, manufacture of electrical machinery and apparatus n. e. c., manufacture of ratio, television and communication equipment and apparatus, manufacture of medical, precision and
} 
- $\quad$ sector of consumer goods production (K sector),

- $\quad$ sector of delivery goods production (P sector),

- $\quad$ sector of investment goods (W sector).

The choice of these sectors is justified by the fact, that they are the main carriers of the technological progress in the Polish industry. In table 1 there are shown indices of the Polish industry's innovation potential, taking into consideration the selected sectors.

Table 1. Indices of the innovation potential ${ }^{\text {a) }}$ of the Polish industry in 2001.

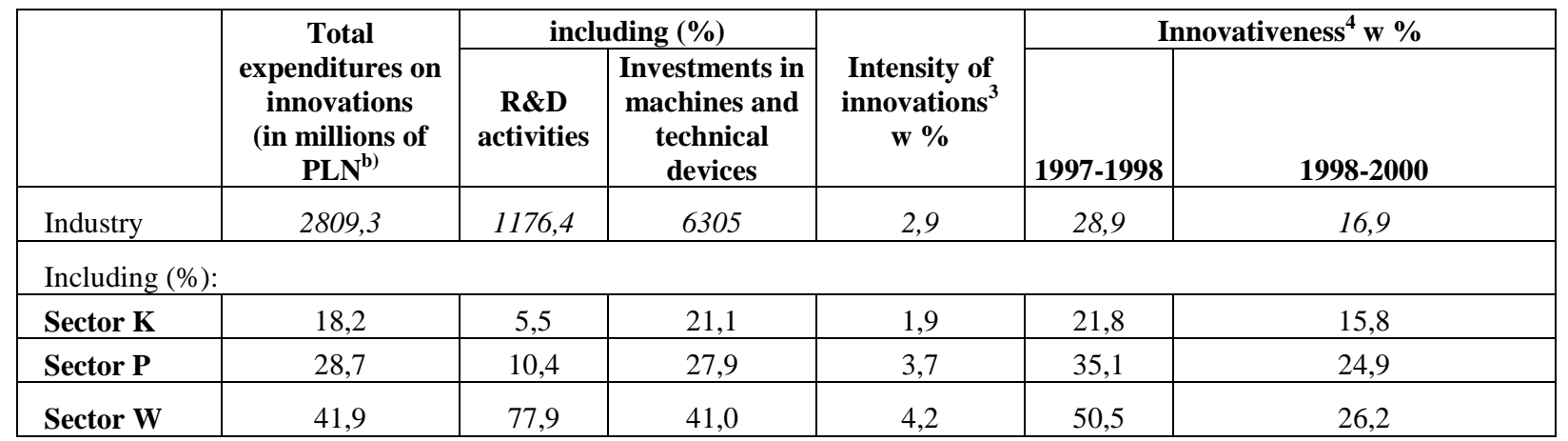

a) Data on the legal entities where the number of the employed exceeds 50 people.

b) $1 \$ \sim 4$ PLN

Source: Own calculations on the basis of [5], [8]

In 1997-1998 the innovations in the W sector were implemented by over $50 \%$ of enterprises i.e. about 20 $\%$ more than on an average in the industry. However, in 1998-2001 this index declined in each sector, but the W sector held a dominating position $(26.2 \%)$. W sector was also characterised by the highest share in the spending on the R\&D of the industry as well as the highest intensity of innovations.

In the circumstances of the strong foreign competitiveness there are some symptoms noticeable concerning the approach of the industrial enterprises towards the innovations' implementation. Enterprises, especially from the investment goods sector appreciated that their competitive advantage, except for the investment in machines and technical devices (53.6-63.5\% spending on innovations) can be also the R\&D activity which amounted to $19 \%$ in this sector (2001). In the $\mathbf{K}$ and $\mathbf{P}$ sectors there is a high share of machines and considerably lower share of the R\&D in the spending on innovations, that results in the decreased share of these sectors in the sold production (tab. 2).

The analysis concerning involvement of the selected industry sectors in the development of the investment in knowledge ${ }^{5}$ shows (fig. 5) that in the $\mathbf{W}$ sector has occurred an index value which is almost twice higher than on the average in the industry. Instead, the rate of involvement of the $\mathbf{K}$ and $\mathbf{P}$ sectors in the development of the intellectual property rights amounted to only from $22 \%$ to $27 \%$ of the average index in the industry. It means that the $\mathbf{K}$ and $\mathbf{P}$ sectors promote new products and unique technological solutions to a small extent, in contrast to the $\mathbf{W}$ sector which to a large extent enriches its knowledge resources.

optical instruments, watches and clocks, manufacture of motor vehicles, trailers and semi-trailers, manufacture other transport equipment, recycling.

${ }^{3}$ Percentage relation of the total spending on innovativeness to the value of the sold production [5].

${ }^{4}$ Percentage relation of the innovative enterprises to the total number of the industrial enterprises. Innovative enterprises - according to the Oslo methodology is an enterprise that in the research term (usually 3 years) implemented at least one technological innovation [4].

${ }^{5}$ This degree is stated by the percentage relation of the spending on the D\&R activity to the value of the investment spending [10]. 
Table 2. Type structure of the spending on the innovativeness in sectors and in industry in 2001.

\begin{tabular}{|c|c|c|c|}
\hline \multirow{2}{*}{} & \multirow{2}{*}{$\begin{array}{c}\text { Share in the expenditures } \\
\text { on innovations in the } \\
\text { industry in \% }\end{array}$} & $\begin{array}{c}\text { R\&D } \\
\text { activities }\end{array}$ & $\begin{array}{c}\text { Investments in machines } \\
\text { and technical devices }\end{array}$ \\
\hline Industry & 100,0 & 10,2 & 54,8 \\
\hline \multicolumn{3}{|c|}{ Including: } \\
\hline Sector K & 18,2 & 3,1 & 63,5 \\
\hline Sector P & 28,7 & 3,7 & 53,4 \\
\hline Sector W & 41,9 & 19,0 & 53,6 \\
\hline
\end{tabular}

Source: Own calculations on the basis of [5], [8]

Fig. 5. The rate of involvement of the industry sectors in the knowledge resources in 1996-2001

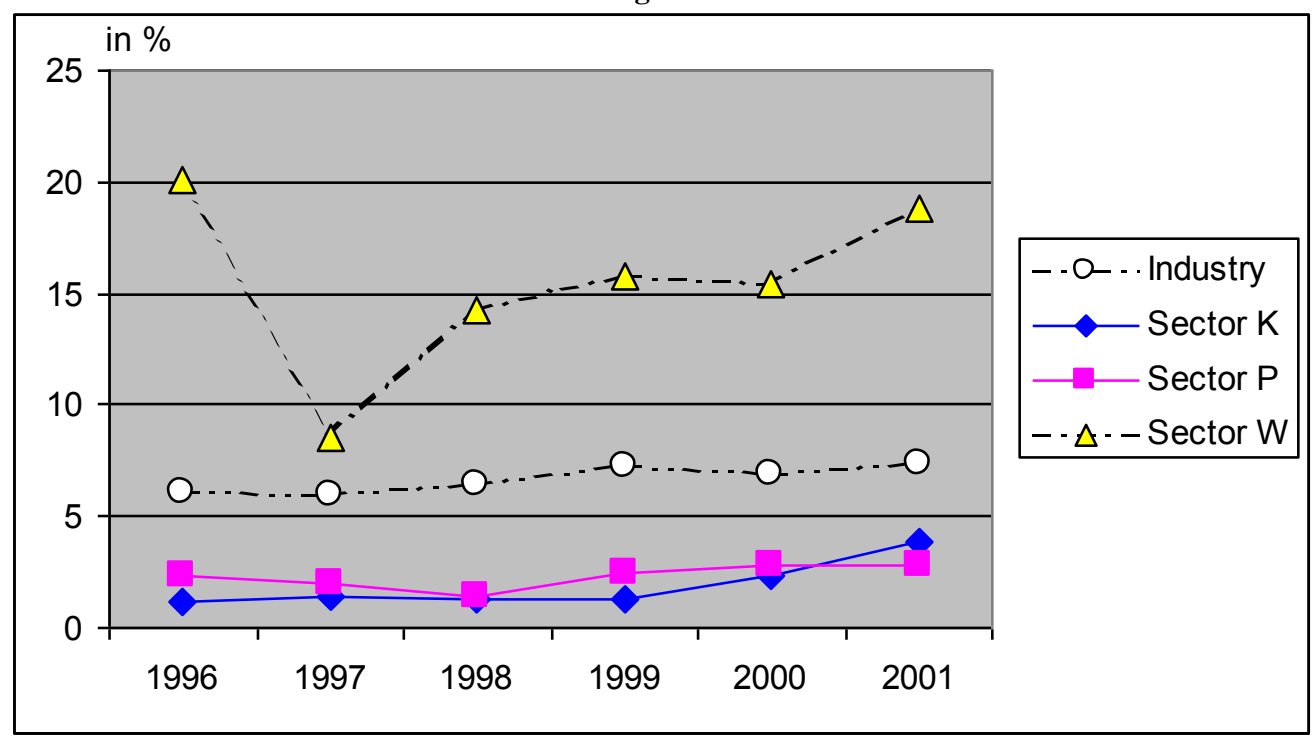

Source: Own study on the basis of [5], [8]

W sector was characterised by the, on average, highest dynamic of the spending on innovations and the highest share in those spending and in 2000-2001 also the level of the innovations intensiveness (fig. 6).

The value of the index of the innovation intensity in the $\mathbf{W}$ sector reached in 2000-2001 which amounted to over $4 \%$ was close to the value of this index in Finland, Germany and France. In the last few years the coefficient of production renovation ${ }^{6}$ decreased. This rate is the main measure of the innovative activity results as well as an index of the competitiveness of the industry (tab. 3).

\footnotetext{
${ }^{6}$ The index indicating the share of the production sold of the products that are technological innovations (new products, considerably improved that are novelties from the point of view of the company launching them), launched into the market within three last years in the total value of the production sold of goods in the particular year [5].
} 
Fig. 6. Intensity of the innovation in the industry sectors in 1994-2001

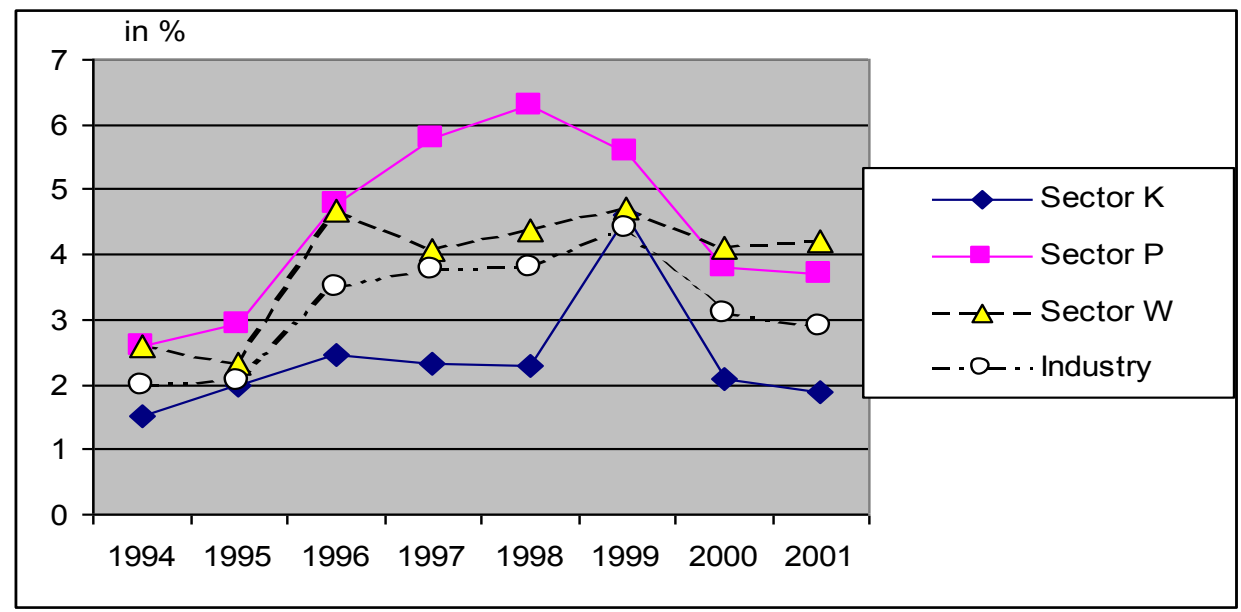

Source: Own study on the basis of [5].

Table 3. The coefficient of production renovation in the industry sectors in 1998-2001

\begin{tabular}{|l|c|c|c|c|}
\hline & \multicolumn{4}{|c|}{ percentage rate of sold production of goods in the years: } \\
\hline & $\mathbf{1 9 9 6 - 1 9 9 8}$ & $\mathbf{1 9 9 7 - 1 9 9 9}$ & $\mathbf{1 9 9 8 - 2 0 0 0}$ & $\mathbf{1 9 9 9 - 2 0 0 1}$ \\
\hline Industry overall & 20,0 & 21,3 & 16,4 & 18,0 \\
\hline Sector K & 8,2 & 9,6 & 11,0 & 13,0 \\
\hline Sector P & 18,1 & 21,2 & 15,5 & 15,7 \\
\hline Sector W & 38,8 & 46,1 & 32,0 & 23,5 \\
\hline
\end{tabular}

Source: Own study on the basis of [5].

\section{Prognostic models of the selected economic indices of innovativeness in Poland}

The improvement of the innovativeness in the Polish industry requires, except for the programmes of the strategic character, the implementation of the organisational and information procedures, including the development of the adequate simulation models that enable:

- $\quad$ identifying of the phenomena and factors influencing the innovativeness,

- collecting of information on the condition of the innovativeness through collecting of reliable statistic data,

- $\quad$ forecasting the trends and regularities.

The issue of the effective creating the innovativeness in the Polish industry was taken up only in the recent years, among others by the authors of this article.

A concept of a hierarchical, multi-level and diffused model was proposed in which the results achieved on the lover level of the hierarchy with the application of the artificial intelligence methods are being used for the inference on the higher level (fig. 7). Such solution allows to set additional economic indices and the synthesis of the obtained results, aiming at the prognosis of the innovative processes. On each level both the implementation of different calculation methods and the extension of the level with modules is possible. The added modules enable to set the partial or aggregated values of the indices. 
The example of prognostic capabilities of the module was presented for the selected industrial sectors for the following economic indices: stage of wear of machines and technical devices, level of machine renovation, intensity of innovation.

Fig. 7. Structure of the prognostic model of the innovation intensity in the industry with the application of the economic indices.

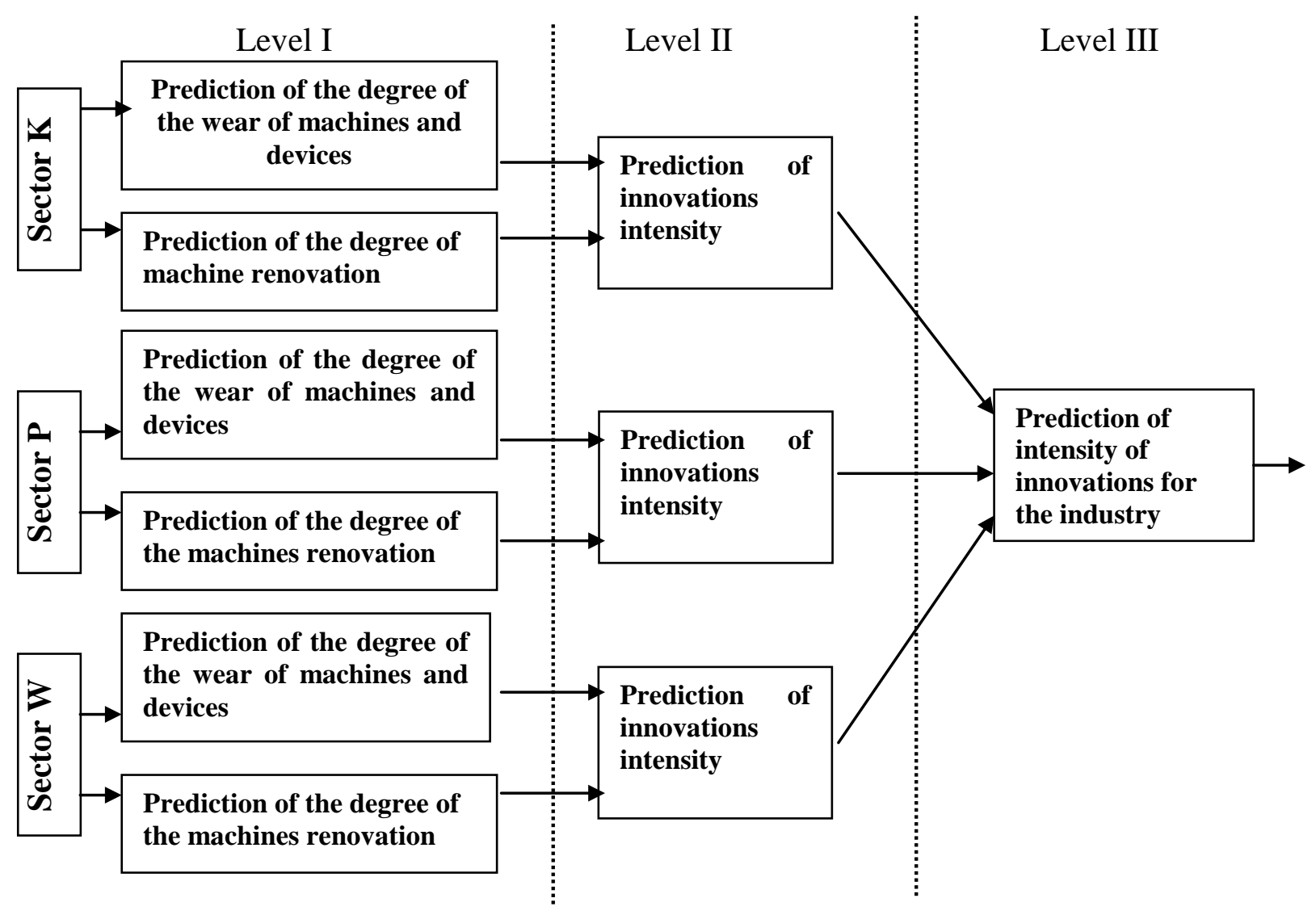

For each level there were neuron networks designed which were used for the forecasting of the indices values on the particular levels. The exemplary structures of networks for the particular levels were presented in figure 8 . 
Fig. 8. Exemplary structures of the neuron networks of the prognostic model.
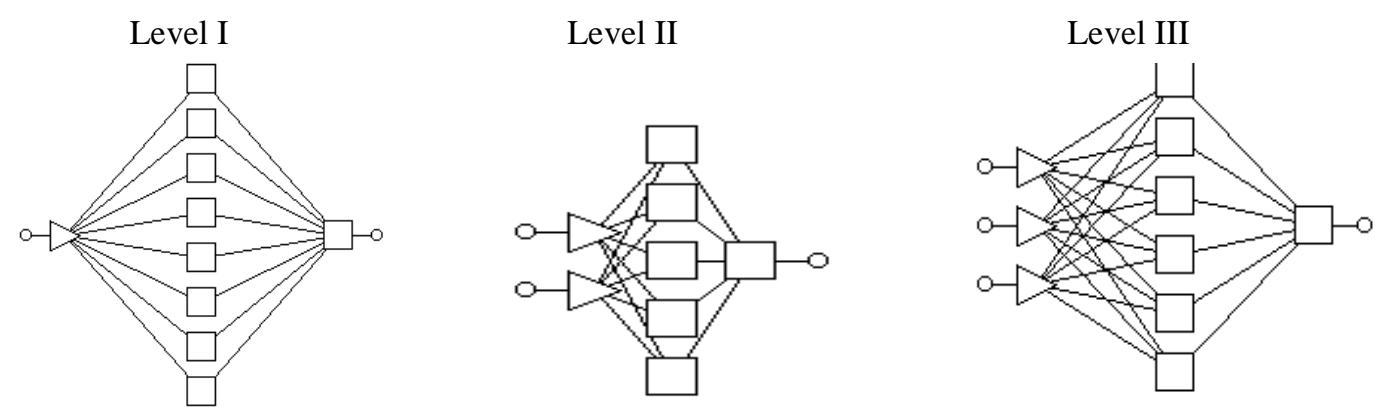

The results achieved with the use of the neuron models in the forecasting of the innovations intensity for the industry were presented in figure 9 and the exemplary results of the forecasts for the stage of wear of machines and technical devices as well as the level of machine renovation in the $\mathbf{W}$ sector were presented in figure 10.

Fig. 9. Results of the innovation intensity forecast on the basis of indices: the stage of wear of machines and technical devices and the level ofmachine renovation in the $K, P, W$ sectors (correlation coefficient 0.9765 )

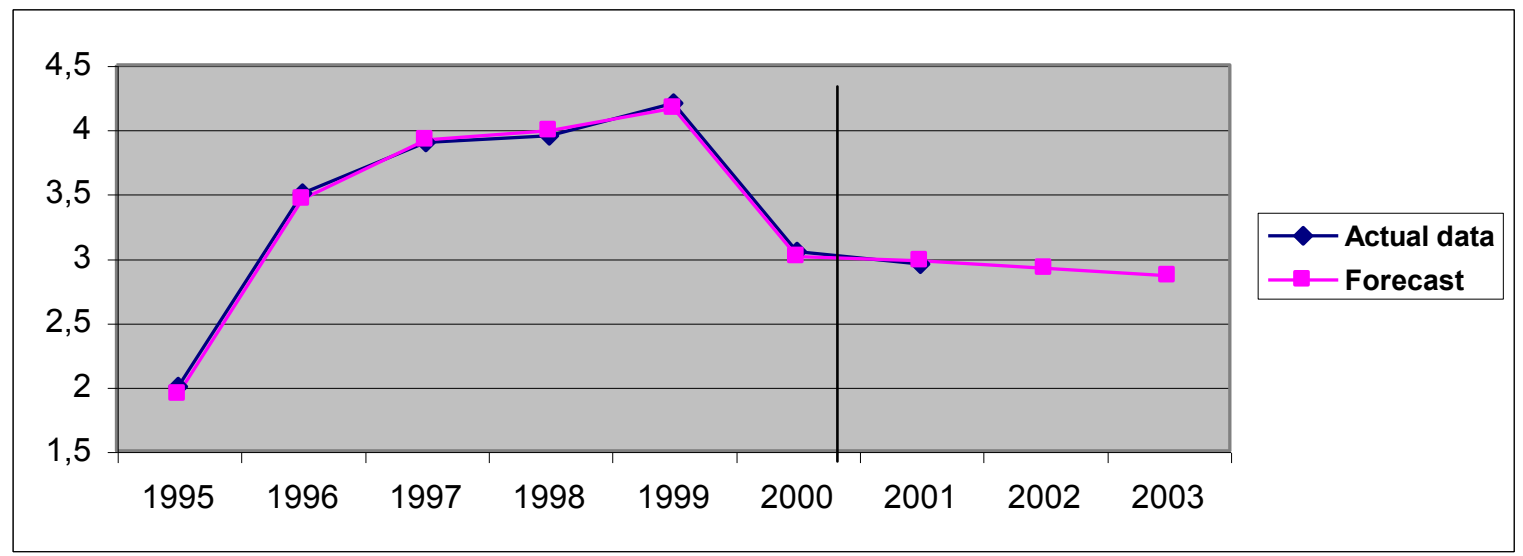

The developed methodology is characterised in particular by:

1. Possibilities of the cyclic teaching of the neuron networks without the necessity of the changing the simulative model.

2. Flexibility: new indices can be taken into account on different levels of hierarchy and the development of the structure networks was automatized through the use of the genetic algorithm method optimisation. 
Fig. 10. Results of the indices forecast: the stage of wear of machines and technical devices (a) and the level of machine renovation (b) in the W sector.

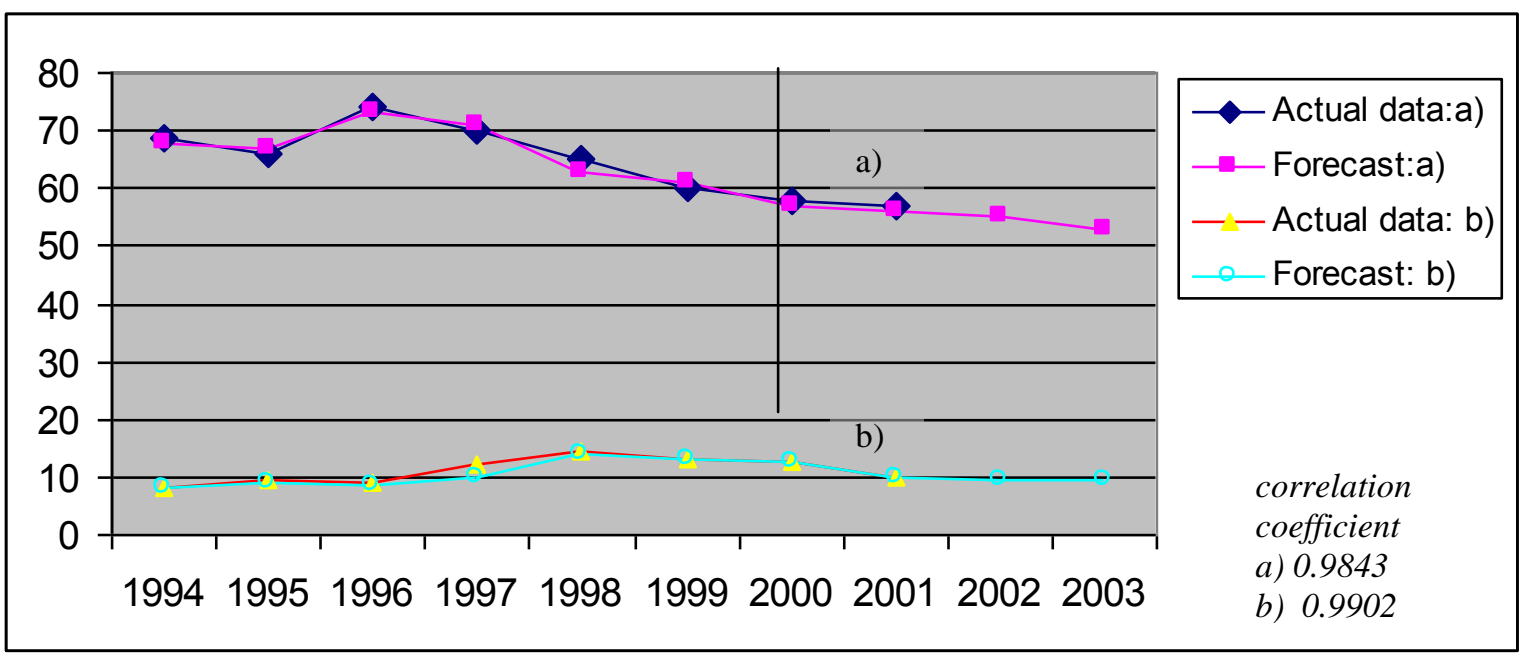

\section{Conclusions}

1. The directions of changes of the innovativeness indices show a very strong connection with the general economic situation in the country. The innovativeness indices undergo even more dynamic changes than the general indices of the economic condition of the country (mainly the declining tendency in the recent years) and that is the result of the high degree (though the lower level) of financing the scientific and research development activity from the State budget.

2. Innovativeness in Poland is characterised by relatively strong scientific and R\&D sector. In Poland there is a high activity and efficacy in gaining the international research programmes, especially those realised within the framework of the European Union. The share of the Polish industry sector in these programmes has been insignificant so far.

3. Transformation of the innovative solution into the industry and the whole economy is high unsatisfactory both considering the industry lacking capital and the lack of the coherent system and specialised organisations of transformation of knowledge to the economic applications and to the transfer of the hightech solutions.

4. The directions of the development of the innovativeness in Poland should concentrate on the technological niches occurring in the world economy, including the development and the production of the singular, hightech machines and technological series and the unique research development and testing appliances as well as in the creating of the specialised information technologies. The Poland's EU accession and making use of the available Structural Funds and the Cohesive Fund for the acceleration of the modernisation and the improvement of the efficiency of all economic sectors should be conductive to the increase of the innovativeness in Poland. The innovative activity should be coherent with the directions set by the EU, in particularly in the area of nanotechnologies and new material technologies.

5. For the forecasting of the trends and concluding the regularities in the innovative processes the models using the artificial intelligence, including the neuron networks presented in this article are very useful. The developed models which use the detailed indices that describe selected sectors or selected kinds of the economic activity, they enable to set a synthetic index that characterises the innovativeness of the whole economy. The accuracy of the simulations, so far not consistent with the demands of the models' authors, will be growing in the effect of complementing the statistic data and including the further modules which regard the interesting aspects of the innovative processes. 


\section{References}

1. Bąkowski A., Wspomaganie innowacyjności przedsiębiorstw przez Programy Ramowe Unii Europejskiej, KBN, Warsaw 2003.

2. Mazurkiewicz A., Sitkowska R., Badanie stanu eksploatacji środków trwałych w gospodarce narodowej, sprawozdania ITeE Radom 1992-2002.

3. Mazurkiewicz A., Sitkowska R., Tendencje w odnowie majątku trwałego przemysłu w warunkach restrukturyzacji gospodarki, „Zagadnienie Eksploatacji Maszyn” 2000, v. 4 (124), p. 155-165.

4. $\quad$ Metodologia Oslo, OECD 1997, KBN Warsaw 1999.

5. $\quad$ Nauka i technika w 2001 roku, GUS Warsaw 2003, p. 104

6. $\quad$ Narodowy Plan Rozwoju 2004-2006, Warsaw, January 2003

7. Raporty o stanie przemysłu w 1999-2002, Ministerstwo Gospodarki, Warsaw $2000-2002$.

8. $\quad$ Rocznik Przemysłu 1999-2002, GUS, Warsaw 2000-2002.

9. $\quad$ Rocznik Statystyczny RP 2002, GUS, Warsaw 2002.

10. Sitkowska R., Measures of technological strategy, Medzinárodna vedecka konferencia „Globalizácia a jej vplyv na transformujúce sa ekonomiky" Rajecke Teplicie 8 - 9 október 2002, p. 269-275.

11. http://www.rzeczpospolita.pl/tematy/case-seminarium/seminaria/podsumowanie2.html

Notes 